Tóth Róbert - Gyurcsik Petronella - Túróczi Imre

\title{
A vállalati pénzügyi kultúra és innováció szerepe Magyarország versenyképességének javításában
}

\section{The Role of Corporate Financial Culture and Innovation in Improving Competitiveness in Hungary}

\section{ÖSSZEFOGLALÁS}

A 2007-2008-ban bekövetkezett globális pénzügyi válság felszínre hozta a rendszerszintû́ kockázatok kezeléséból fakadó problémákat, mikrogazdasági és makrogazdasági szinten egyaránt. Ezen idôszak meglehetôsen nehéz próba elé állította az egyes országok teljes gazdasági rendszerét, beleértve valamennyi gazdasági szereplô helyzetét is. A válság után bekövetkezett változások megfelelő tudatosságot, pénzügyi elhatározottságot igényelnek a piaci szereplőktôl, amely gondolat elvezet a megfelelô szintú pénzügyi kultúra és az innováció szükségességéhez. Összességében elmondható, hogy a pénzügyi ismeretek szintje, az innovációs képesség hatással van mind a vállalkozások, mind az egész nemzetgazdaság stabilitására, növekedési lehetôségeire és versenyképességére, így a pénzügyi kultúra fejlesztése kiemelt nemzeti érdek.

Journal of Economic Literature (JEL) kódok: O11, O44, G41

Kulcsszavak: pénzügyi válság, pénzügyi kultúra, versenyképesség, vállalkozások

Tóтн RóвERT doktorjelölt, SZIE GSZDI, elemzó közgazdász, Magyar Kereskedelmi és Iparkamara (toth.robert@mkik.hu), Gyurcsık PetronelLA doktorjelölt, SZIE GSZDI, osztályvezetô, Nemzeti Adó- és Vámhivatal (gy.petronella01@gmail.com), DR. Túróczi ImRe fôiskolai tanár, Debreceni Egyetem, címzetes egyetemi tanár, SZIE (turoczi.imre@t-online.hu). 


\section{Tudományos múhely}

\section{SUMMARY}

The 2007-2008 global financial crisis exposed the problems arising from systemic risk management, on both a micro- and a macroeconomic level. This period was particularly challenging for the entire economic systems of the individual countries, including all the participants of the economy. Post-crisis changes require appropriate awareness and financial decisiveness from market operators, and this leads to the need for an adequate level of financial culture and innovation. Overall, the level of financial literacy and the capacity for innovation have an impact on the stability, potential for growth and competitiveness of the entire national economy. Therefore, improving financial culture is a key national interest.

Journal of Economic Literature (JEL) codes: O11, O44, G41

Keywords: global financial crisis, financial culture, competitiveness, companies

\section{Bevezetés}

Az elmúlt évtizedben a gazdasági élet szereplői, a jövố vállalkozói és a gazdasági szakemberek még mindig vissza-visszautalnak a válságra, annak tartós hatásaira, és figyelembe veszik, hogy a 2007-es válság egyaránt sok változást hozott a világgazdaságban és Európában. Bod Péter Ákos (2018) könyvében a következôképpen utal erre a jelenségre: „Aztán beütött 2008 ôszének válsága Európában, és különös erôvel Magyarországon. Ezzel gyökeresen megváltoztatta a rá következó fiatal korosztály társadalmi kondicionáltságát: a mai egyetemi hallgatók úgy nôttek fel, hogy amióta a világ dolgairól hallanak, mindig valamilyen válságról van szó..."
De ezt erôsíti Gary B. Gorton 2012-ben megjelent könyve is, aki írásában rávilágít arra, hogy a pénzügyi válság kirobbanása a közgazdász-társadalom többségét váratlanul, felkészületlenül érte. Megjegyzi továbbá, hogy „egy válság személyes átélését nem helyettesíti az, ha csak könyvekból olvasunk róla. Aki aktív résztvevôje, átélője volt a krízisnek, vagy megtapasztalta annak negatív kihatásait, az másképpen fog ezután a pénzügyi válságokról gondolkozni..." (Gorton, 2012).

A 2008-as válság rávilágított arra, hogy a gazdaság szereplőinek változtatnia szükséges annak érdekében, hogy a jövôben elkerülhessünk egy hasonló méretú gazdasági recessziót. Ennek kulcsa lehet a pénzügyi magatartásban végrehajtandó változás, amely az ország versenyképességének javításában is meghatározó szerepet tölt be (Lentner, 2019). Mind a bankári tevékenységben, mind a vállalkozói magatartásban, mind pedig az állami szerepvállalásban tisztázni szükséges a felelősség kérdéskörét, valamint kiemelten fontos a felelôs gazdálkodás, a felelôs hitelnyújtás és a pénzügyi tudatosság erôsítése.

A fentiekben megfogalmazott célok, vagyis a pénzügyi magatartásban szükséges paradigmaváltás elérése érdekében kiemelt feladatnak is tekinthetô, egyben tanulmányunk további céljai a következôk:

- felhívni a vállalkozások figyelmét, hogy az egyre gyorsuló ütemben, turbulens módon fejlôdó pénzügyi és vállalkozói környezetnek megfeleló ismeretekre, innovációvezérelt gondolkodásmódra van szükségük;

- ösztönözni a vállalkozásokat, hogy a pénzügyi eredményekre való törekvés mellett kapjon szerepet az operatív mú- 
ködésben a kockázatok azonosításának és mindenkori mérséklésének, diverzifikálásának igénye;

- tudatosítani a vállalkozásokban, hogy tốkeszerkezetük optimalizálása kulcsfontosságú az eredményes múködés tekintetében;

- rávilágítani arra, hogy a hiányos pénzügyi képzettség, a pénzügyi (szak)ismeretek hiánya negatívan hat a vállalkozások jövedelmezôségére, és ronthatja a hatékonyságukat is, illetve jelentôsen képes gátolni a cégek növekedését, beruházási döntéseit.

Tanulmányunk további célja megfogalmazni a versenyképesség és a pénzügyi kultúra összefüggéseit, ezzel alátámasztva a pénzügyi tudatosság makrogazdaságra gyakorolt kedvezô hatásait. Ezenkívül kiemelt figyelmet fordítunk az innovációra mint versenyképességi tényezốre. Itt jegyezzük meg, hogy a munkánkat a szakirodalmi, elméleti áttekintés helyett az aktualitásokra és saját véleményünkre építjük.

\section{A VERSENYKÉPESSÉG JAVÍTÁSÁNAK} FELTÉTELEI

A magyar gazdaság versenyképességének fokozása kiemelt stratégiai célkitúzés, amely mind mikrogazdasági, mind makrogazdasági szinten értelmezhetô. Ezen kiemelt kormányzati célkitúzés teljesítésében meghatározó szerepet tölt be a magyar tulajdonú kis- és középvállalati szektor. Tekintettel arra, hogy a hazai kkv-szektor gazdasági teljesítményt stabilizáló, kiegyensúlyozó szereppel bír, így annak széles körú támogatása a jövố egyik legfontosabb kulcskérdésének tekinthetô. Minderre tekintettel kiemelt fontosságú ezen szektor mindenkori fej- lesztése, pénzügyi kultúrájának erôsítése, a tágan értelmezett külsố környezethez történố alkalmazkodásuk támogatása. Kiemelt feladat annak ösztönzése, hogy ezen gazdasági szereplốk a termelési és/ vagy szolgáltatásnyújtási tevékenységüket minél magasabb szinten, kimagasló minôségben végezzék, így biztosítva a magas hozzáadott érték generálását.

Napjaink gazdasági folyamataiban talán az egyik legfontosabb versenyképességi tényezónek tekinthetố, hogy egy gazdálkodó szervezetnek milyen hozzáadott érték elóállítására képes egy vállalat, hiszen ezáltal nyílik lehetôsége arra, hogy be tudjon lépni a hazai, illetve az uniós beszállítói - és ellátási - láncokba. A gazdasági versenyképesség további kritériumainak a gazdasági szereplók termelékenységét, hatékonyságát és pénzügyi tudatosságát tekintjük, valamint azon kompetenciájukat, hogy ezeket képesek legyenek - a kor technikai, társadalmi követelményeinek megfelelóen - folyamatosan megújítani és fejleszteni.

Közismert, hogy a termelékenység alakulása sok tényezố együttes függvénye, ezért annak növelése is soktényezôs, komplex feladat. Ezért az egyes komponensek változása, változtatása nem elegendó, egyes elemek egyoldalú kiemelt kezelése akár kétélú fegyver is lehet, vagyis a termelékenység csak az egyes faktorok közötti kölcsönhatások figyelembevételével javítható. Jó példa erre, hogy Magyarországon az elmúlt években hiába javulnak számottevôen a makrogazdaság mennyiségi mutatói (foglalkoztatás, GDP, államadósság, munkanélküliség, beruházások volumene stb.), ha ezzel párhuzamosan nincs javulás a hatékonysági, tudatossági és intézményi tényezốkben, akkor a Globális Versenyképességi Index sem 
tud számottevốen pozitív irányba változni.

További versenyképességi tényezônek tekinthetô a tartósan magas növekedés, amelynek feltételeként az alábbiakat fogalmazzuk meg: ${ }^{1}$

- nyitott, a világgazdaságba szervesen beintegrálódott gazdaságok (amelyek versenyképes, hatékony, a GDP növekedéséhez határozottan hozzájáruló exporttal, magas tôkevonzó és -kihelyezô képességgel, pozitív külkereskedelmi és folyó fizetési mérleggel rendelkeznek, amely pozitív fizetési mérleg képes kordában tartani az eladósodottságot);

- makrostabilitás (hosszú távon fenntartható, kiegyensúlyozott növekedés, relatíve kicsi eladósodottság és relatíve alacsony munkanélküliség);

- alacsony külsố és belsố eladósodás (azaz nem alakul ki az ún. ikerdeficit, amit nagyon nehéz és fájdalmas egyidejûleg kezelni);

- magas megtakarítási ráta a háztartásoknál (amely a növekedés mellett kedvezôen hat az állami önfinanszírozásra, vagyis a stabilitásra, így csökkenti az ország kitettségét, külsô sérülékenységét is);

- magas beruházási ráta (ami alapvetôen a hazai forrásokon, a relatíve magas lakossági megtakarításokon alapul);

- az erőforrások piacvezérelte allokációja (az államnak határozott szerepe van a stratégiai célok kitúzésében, az ennek megfelelố szabályozórendszer kialakításában, sportnyelven szólva a futball szigorú játékszabályait a központi szabályozó alakítja ki, de a pályán már minden csapat a szabályoknak megfelelóen, a legjobb tudása szerint maga futballozik, versenyez);

- rugalmas munkapiac (vagyis a bérek és a létszám függvényében meghatáro- zott, hosszú távú egyensúlyi trendhez való visszatérés sebessége) (Pula, 2005);

- egyértelmúen definiált a közjavak köre (amelyek a relatív fejlettséghez képest szociális biztonságot és fejlôdési lehetőséget biztosítanak az egyének számára, akik ezáltal könnyebben azonosulnak a központi döntéshozatallal; ezen szolgáltatások garantálásában fontos a közösségi beruházások szerepe, melynek kiemelt területei: infrastruktúra, egészségügy, oktatás, kutatás-fejlesztés);

- hiteles, áttekinthetô, magas szakszerúséget képviselő, olcsó kormányzás;

- optimális, versenyképes adórendszer (amely a hatékonyságra, egyszerúségre és igazságosságra törekszik, amely az adóterhelés minimalizálásával segíti a növekedést, de mindezek ellenére képes biztosítani a szükséges állami bevételeket);

- tudatos vállalati kultúra, magas pénzügyi kultúra.

A versenyképesség jelentôs javítása és a jelenlegi kedvezó ütemú gazdasági növekedés fenntartása érdekében azonban komoly kihívásokkal kell szembenéznie a szektornak. Ilyen a jelenlegi gazdasági és társadalmi rendszereket érintô digitális transzformáció. Mindez egészen pontosan azt jelenti, hogy azon vállalatoknak, amelyek a mostani éles versenyben megfelelô pozícióban szeretnének maradni, változtatniuk szükséges számos, a vállalkozást érintô területen (beszerzés, értékesítés, logisztikai és szállítási folyamatok, CRM-rendszerek, vállalatirányítási rendszerek stb.). Azt mondhatjuk, hogy egy részben vagy egészében új üzleti modellel kell megjelenniük, amely segíti óket a versenyhelyzetük stabilizálásában, javításában.

Mindez szorosan összefügg az innováció folyamatos igényével, ami részben a fogyasztói szokások gyors átalakulásá- 
ra vezethetố vissza. Az innovációs tevékenységek pedig tudatosságot, jövó- és teljesítményorientáltságot, pénzügyi és humántôke-erôforrást követelnek meg a vállalkozóktól, amelyek szintén nem kis kihívásnak tekinthetők.

A következố terület pedig éppen az elôzốekre vezethetô vissza: ma már látható, hogy sok esetben a növekedés gátja a megfelelô humán tốke rendelkezésre állása. Meg kell szólítani azokat a szakembereket, akik a mai kor elvárásainak megfelelố választ képesek adni. Ami pedig talán még fontosabb, az nem más, mint a munkavállalók megtartása, motiválása, fejlesztése. Ennek mindenképpen meg kell jelennie stratégiai szinten, hiszen máskülönben versenyképességi hátrányt jelent közép- és hosszú távon.

Amennyiben röviden jellemezni szeretnénk az aktuális magyar munkaerôpiacot, úgy fogalmazhatnánk: feszített munkaerôpiac jellemzi hazánkat. A legfrissebb KSH-jelentés szerint a júniusiaugusztusi időszakban a munkanélküliek átlagos létszáma 157 ezer fó, a munkanélküliségi ráta 3,4\% volt, ami továbbra is rekordalacsony szintnek mondható. Az elmúlt években azt láthattuk, hogy az egyes kormányzati intézkedéseknek, a kedvezó üzleti környezetnek és a világpiaci folyamatoknak köszönhetôen fokozatosan mérséklődött a munkanélküliségi ráta. Azonban kijelenthetô, hogy a munkaerôpiac jelenlegi tartalékai már csak nehezen strukturálhatók át, ami egyben azt is jelenti, hogy a munkanélküliség lassan csökkenhet tovább. Az elmúlt idôszakban egyre több elemzó és cégvezetố kommunikációjában hangzott el, hogy a magyar munkaerópiac mennyiségi korlátokba ütközik, azaz számos olyan terület mutatható ki, ahol munkaerôhiány van. A másik fontos aspektus annak megvizsgálása, milyen minôségú a még rendelkezésre álló munkaerô. Hiszen látható, hogy egyre több olyan munkahely, pozíció születik, ahol a speciális szaktudás és tapasztalat nélkülözhetetlen (tudásalapú társadalom felé haladva ez még inkább elôtérbe kerül). Egyre inkább az tapasztalható, hogy a nehezen foglalkoztatható és gyakran teljesen képzetlen munkaerőréteg maradt még szabadon - ami pedig egyértelmúen magával vonja az oktatás felértékelôdését, amelyet állami (szakpolitikai) szinten szükséges kezelni, de természetesen mikroszinten, a vállalkozásoknak is meghatározó szerep jut mindebben.

A fentieken túlmenően érdemes megvizsgálni azt is, hogy a fluktuáció mennyire van jelen a hazai munkaerópiacon, és annak mértéke mennyire gyengíti a vállalkozások - a kisvállalkozások és a nagyobb cégek - múködését, teljesítményét és hatékonyságát. A turbulensen változó üzleti környezetben, az egyre inkább kimutatható szakemberhiány miatt a tehetséges munkatársak megtartása a vállalati stratégia egyik központi kérdésévé vált. Egyre több munkavállaló számára fontos, hogy folyamatosan tanuljanak valami újat, ami egyben azt is jelenti, hogy a munkahelyeknek biztosítaniuk szükséges ezeket a munkavállalói elvárásokat. Vállalati beszámolók alapján megállapítható, hogy a „munkaerô-vándorlás” gondot jelent a vállalatok számára, ami arra kényszeríti a cégeket, hogy állandóan monitorozzák, miként minimalizálható a folyamat. Meglátásunk szerint a fluktuáció csökkentésének egyik lehetséges módja a különféle szakmai képzések lehetôségének biztosítása. A képzések egyrészt fejlesztik a munkavállalót, aki így hatékonyabban képes végezni a munkáját (egyben a vállalati 


\section{Tudományos múhely}

komplex hatékonyság is javulhat), ezáltal növekedhet a munkavállaló megbecsülése és bérezése is. A vállalati gyakorlat azt mutatja, hogy a munkavállalók akkor érzik a megbecsülést egy munkahelyen, ha a vállalat tudatosan támogatja a fejlódésüket. Álláspontunk szerint a specifikus képzések egyértelmúen hozzájárulnak a vállalati kultúra erôsítéséhez is, így egy tudatosan felépített humánfejlesztési stratégia rengeteg elónyt hozhat a vállalkozások számára.

A humán tôkével kapcsolatban pedig felmerül a generációváltás, utódlás kérdése is. E jelenség alapvetốen a családi vállalkozásoknál okoz problémát. Ezen vállalkozások jelentôs részét a rendszerváltás után alapították, így az akkori alapítók mára jórészt elérték a nyugdíjkorhatárt. A BGE Budapest LAB Vállalkozásfejlesztési Központ kutatásából kiderül, hogy az alapítók saját bevallása szerint a cégek valamivel kevesebb, mint harmadánál nincs kinek átadni sem a tulajdont, sem a vezetést, így nyugdíjba vonulásukkal várhatóan a cég is befejezi múködését (Heidrich, 2018). De az utód(ok) megléte ellenére sem biztosított a sikeres tulajdonos-, menedzsmentváltás, a családi vállalatok kétharmada nem éli túl a generációváltást (Konczosné-Kézai, 2018). Ez pedig nemzetgazdasági szempontból is súlyos következményekkel járhat. Kardinális kérdés, amely meghatározza hazánk jövôbeni vállalati szerkezetét, teljesítôképességét. Látni kell, hogy a tudatosság, a megfelelố utód kiválasztása, a tapasztalatok és a vállalatspecifikus ismeretek átadása nagymértékben képes befolyásolni a jelenlegi vállalkozások jövôbeni teljesítményét. Minderre tekintettel, ezen kérdés célzott és irányított kezelése, menedzselése is létfontosságú. Ugyanakkor, ahol nem megoldható a családon belüli utódlás, ott racionális döntés lehet a cégeladás. Ebben az esetben pedig finanszírozási forrást jelenthet az MFB Generációváltási Tốkeprogramja, amelynek célja, hogy a forráskiegészítô tốkeprogram révén segítse a cégfelvásárlások finanszírozását, és erôsítse a hazai kkv-szektor M\&A-aktivitását. ${ }^{2}$

Nemzetközi tapasztalatok alapján kijelenthetô, hogy azok a vállalkozások (és nemzetgazdaságok), amelyek globális értékláncokba integrálódnak, és exportpiacra is termelnek, szolgáltatnak, sokkal versenyképesebbek, eredményesebbek, pénzügyileg stabilabbak. A hazai piac meglehetôsen szúk, így a magyar vállalkozók alapvetố igényei között meg kell hogy jelenjen az aktív exporttevékenység. Ezt pedig támogatni, ösztönözni szükséges, hiszen az exportpiacon megjelenó vállalkozások valószínúleg magasabb hozzáadott értéket állítanak eló, ami egyben együtt jár a magasabban képzett szakemberek alkalmazásával, tehát a tudással. A tudás pedig szintén versenyképességi tényezô, és cél kell hogy legyen, hogy Magyarország is rövid idôn belül tudásra és innovációra épülô gazdasággá váljon.

Meglátásunk szerint a hazai cégeknek szemléletváltásra van szükségük annak érdekében, hogy megtalálják a külföldi piacokban még kiaknázatlan lehetôségeket. Rengeteg kiváló, évek óta prosperáló, magyar tulajdonban lévô vállalkozás van a piacon, amelyek motiváció és ösztönzés hiányában eddig nem eszközöltek lépéseket a külföldi piacok felé. Azt gondoljuk, hogy a stabil gazdaságpolitika, az egyre inkább vállalkozóbarát üzleti környezet, a célzott kormányzati intézkedések a jövốben kellố ösztönzést adnak a hazai cégeknek az exportpiaci terjeszkedésre. 
Kiemelendô továbbá, hogy napjainkban egy digitális transzformáció zajlik az üzleti világban is, így a vállalkozók egy része ma még keresi azokat az eszközöket, amelyekkel meg tud felelni a 21. század kihívásainak. Úgy gondoljuk, hogy innovációval, aktív stratégiával, magas hozzáadott értékkel és kiváló tudással a hazai cégek a jövôben jelentôs növekedést realizálhatnak nemzetközi szinten.

Közismert tény, hogy azon vállalkozások, amelyek a hazai piacon túl a nemzetközi gazdasági folyamatoknak is aktív részesei, eredményesebben, hatékonyabban képesek folytatni múködési tevékenységüket. Ahhoz azonban, hogy egy vállalat beszállítói pozícióba kerüljön, és esetlegesen az exportpiacon is megjelenjen, hatékonynak, jövedelmezónek, értékteremtônek és tanulásra képesnek is kell lennie egyszerre. Mindezen felül a termelékenység növeléséhez (Vakhal-Palócz, 2018) és gazdasági helyzetük optimalizálásához a mai kornak megfelelố technológia rendelkezésre állása szükséges, illetve elengedhetetlen, hogy legyenek olyan proaktív, a mai környezet kihívásaira nyitott cégvezetốk, akik ezeket a technológiákat, innovatív megoldásokat hatékonyan tudják integrálni mindennapi tevékenységükbe.

$\mathrm{Az}$ exporttevékenységgel összefüggésben világítunk rá az árfolyam kérdésére, mely nem hagyható figyelmen kívül. Gyakran ismételt érv a nemzeti valuta folyamatos gyengülése kapcsán, hogy mindez elónyös a gazdaság számára, tekintve, hogy ösztönzi az exportot, munkahelyeket teremt, így hozzájárul a növekedéshez, összességében pedig javítja versenyképességünket. Napjainkban pedig éppen ez a tendencia figyelhetó meg, vagyis a forint árfolyamának gyengülése. Ugyanakkor megjegyezzük, hogy mindez elsôsorban Magyarországtól független nemzetközi gazdasági folyamatokra vezethetô vissza (Brexit, a kereskedelmi háború, az Európai Központi Bank új gazdaságélénkítô programja, a lassuló német ipari növekedés vagy éppen a német autóipar kedvezótlen helyzete; de olyan további nemzetközi folyamatok is hatással lehetnek, mint a világgazdaság bővülésének lassulása, az új Európai Parlament és az Európai Bizottság felállása, az új uniós költségvetési ciklus, az amerikai elnökválasztás, az euróövezetben tapasztalt gazdasági gyengélkedések, az olajpiaci helyzet stb.). Itt szeretnénk rávilágítani két dologra: egyrészt az export tekintetében érdemes mindig megvizsgálni azt is, hogy az exportált terméknek mekkora az importigénye (hiszen a gyenge árfolyam drágítja az importot), tekintve, hogy az a végsố eredményre jelentôs hatást gyakorol. Másrészt tudatosítani kell a vállalkozásokat a tekintetben, hogy az exporttevékenység során ne az árfolyam legyen az elsôdleges motivációs tényezô. Sokkal inkább arra kellene ösztönözni óket, hogy folyamatosan legyen olyan termékük és/ vagy szolgáltatásuk, amelyekre - függetlenül az éppen aktuális árfolyamtól - nemzetközi szinten igény van.

A vállalatok versenyképességére hatással van a pénzügyi és vállalkozói kultúra is, így fejlesztése kiemelkedô fontosságú napjainkban, hiszen a gazdaság szereplôi kizárólag megfelelố minôségú és menynyiségú információ birtokában képesek felelôs döntéseket hozni. Végsố célként megfogalmazható, hogy a magyar üzleti szféra pénzügyi tudatosságának szintje rövid idôn belül nemzetközi összehasonlításban az élmezónybe kerüljön.

További korlátozó tényezônek a hazai kkv-szektor alacsony termelékenysége te- 
kinthetô. Fontos rávilágítani arra, hogy mindez jelentôs növekedési tartalékként értelmezhetố a magyar gazdaságban. Nézzük meg részletesebben, miért is fontos a szektor produktivitása. Annak ellenére, hogy ez a szektor adja a teljes foglalkoztatás mintegy 73 százalékát, a GDP-nek csupán az 50 százalékát állítja elô, és az exportból csak 20 százalékban részesülnek a hazai kkv-k. Megjegyezzük továbbá, hogy az átlagos magyar kis- és közepes vállalkozások termelékenysége egyharmada a nagyvállalatokénak. Hazánkban a nagy méretú, multinacionális cégek termelékenysége több mint másfélszerese a hazai átlagnak, miközben a számarányában meghatározó, 9 fónél kisebb, szinte teljes mértékben magyar tulajdonú kisvállalkozások termelékenysége a hazai átlag fele, az egyfốs mikrovállalkozásoké pedig ennél is kisebb. Mindezt tekintve, a hazai és a külföldi vállalkozások vonatkozásában a termelékenységi különbség többszörös (3-4-szeres) is lehet. Megjegyezzük, hogy Európában nálunk az egyik legnagyobb a termelékenységi szakadék a nagyvállalatok és a kkv-k között. A kkv-k termelékenységi problémáit szemléltetik az alábbi összehasonlító adatok: a kkv-k számaránya és az ott foglalkoztatottak aránya az összes foglalkoztatotton belül nagyjából azonos az Európai Unióban és hazánkban. Ám uniós átlagban a kkv-k a hozzáadott érték 56\%-át termelik, míg nálunk a GDP mintegy 40\%-át. Az EU-ban a nettó árbevétel 56\%-a, nálunk 42\%-a származik a kkv-szektorból. Az Európai Unióban az összexport több mint 50\%-a, Magyarországon alig több, mint 20\%-a, az innovációk kevesebb mint 10\%-a kötődik hozzájuk. Az EU-ban a beruházások valamivel több, mint 40\%-a, nálunk 30\%-a kapcsolódik hozzájuk. A fentieken túl so- katmondó az is, hogy a magyar kkv-k átlagos hozzáadott értéke nem éri el az uniós átlag felét. Egy német mikrovállalkozás termelékenysége legalább a négyszerese egy hasonló hazainak. A V4-ekkel való öszszehasonlításban is sereghajtók vagyunk, a hazai kkv-k termelékenysége több mint 10\%-kal alacsonyabb, mint a V4-es társaiké.

Mindez azt jelzi, hogy ezen a területen számos beavatkozási cselekvésre lenne szükség. Ezt igazolja többek között, hogy a Magyar Nemzeti Bank versenyképességi programjának is egyik fontos részét képezi a kkv-szektor termelékenységének javítása. Az MNB tanulmánya szerint évi 6 százalékos növekedéssel 2030-ra kétszeresre csökkenthetố a mostani különbség a kkv-k és a nagyvállalkozások termelékenysége között. A termelékenység javítása többek között a technológiai készség és képesség javításával, az innovációs tevékenység fokozásával, valamint a humán tốke képzettségének javításával érhetô el. Ezen a területen mihamarabbi lépések eszközölésére lenne szükség, tekintve, hogy amennyiben a szektor termelékenysége elérné a régió átlagát, és így közelebb kerülne a nagyvállalatokéhoz, akkor mindez 3-5 százalékkal növelné a magyar bruttó hazai terméket (az MNB számításai alapján).

Érdemes rávilágítani egy további tényezôre, ami szintén összefüggésben áll a termelékenységgel. A magyar gazdaság növekedését, a vállalkozások prosperitását a rendelkezésre álló munkaerô is jelentôsen befolyásolja (lásd fentebb). Ma már egyértelmú, hogy mindezt nem az alacsony bérekkel lehet elérni, sốt éppen ellenkezóleg: az sok esetben már a termelékenység gátját is jelenti (a bérnyomás miatti fluktuációt tekintve). 
A PÉNZÜGYI KULTÚRA FEJLESZTÉSÉNEK CÉLJAI

A pénzügyi kultúra folyamatos fejlesztése egyre gyakrabban megfogalmazott célkitûzés a nemzetgazdaságokban, így hazánkban is, ahol a 2017-ben meghirdetett „Pénzügyi tudatosság fejlesztésének stratégiája" konkrét célokat, hozzájuk kapcsolódó cselekvési terveket fogalmaz meg, és szervezeti keretet ad a lakosság pénzügyi kultúrájának fejlesztéséhez, hiszen a pénzügyi kultúra szintje, annak minôsége valamennyi gazdasági szereplố közös érdeke (Tebeli, 2018). Az elmúlt néhány évben számos nemzetközi tudományos tanulmány alátámasztotta, hogy a pénzügyi kultúra minôségének javítása nemcsak a háztartások és a vállalkozások, hanem az állam érdeke is, hiszen azok a nemzetgazdaságok, amelyek magasabb szintû pénzügyi kultúrával rendelkeznek, többnyire versenyképesebb - így a nemzetközi versenyképességi listákon is elônyösebb - pozícióban helyezkednek el (Tóth et al., 2018). Érdemes továbbá rávilágítani arra is, hogy a magasabb szintú pénzügyi kultúrával rendelkezô háztartások és gazdálkodó szervezetek nagyobb valószínúséggel kerülik el azokat a pénzügyi döntéseket, amelyek hátrányosak számukra, és hoznak inkább olyan gazdasági - és pénzügyi - döntéseket, amelyek pozitív hatást gyakorolnak a vállalkozás múködésének egészére. Mindez pedig áttételesen hozzájárul az adott ország pénzügyi rendszerének stabilitásához, valamint az államháztartás bevételeinek növeléséhez a pénzügyi kultúra részének tekinthetô adótudatosság erôsítése révén (Sinkáné, 2018). A fentiekból látható, hogy a magánszemélyek pénzügyi tudatosságát nem lehet elválasztani a cégvezetôk tudatosságától, azokat érdemes együtt vizsgálni. Összességében tehát kijelenthetô, hogy Magyarország stabil, fenntartható gazdasági növekedéséhez, versenyképességének fokozásához pénzügyileg tudatos, széles körú és a mai kornak megfelelố ismeretekkel rendelkezô lakosságra és vállalatokra van szükség.

Ennek elérése érdekében tehát egy pénzügyileg tudatos vállalkozói kör kinevelésére van szükség, amely lehetôséget teremthet arra, hogy makrogazdasági, nemzetgazdasági szinten is stabil múködés legyen jellemzố a hazai gazdaságra. Ennek okán kiemelten fontosnak tartjuk a következóket:

- A vállalatoknak tudatos tervezésre lenne szükségük, olyan pénzügyi stratégiák kialakítására, amelyek teljeskörúen szolgálják a vállalati stabilitást, a teljesítmény fokozását. A jelenlegi globalizált világgazdaságban a gazdálkodó szervezeteknek egyre nagyobb hangsúlyt kell fektetniük azoknak a vezetési rendszereknek az alkalmazására, amelyek elsôsorban pénzügyi döntéstámogató információkat tartalmaznak, ezzel segítve a menedzsment tervezési, stratégiaalkotási, befektetésstruktúra-kialakítási munkáját.

- Közismert tény, hogy a vállalati növekedésben meghatározó szerepet játszanak a külsố pénzügyi források, a pénzintézeti hitelek. Ezeket a jövôben is igénybe kell venniük a vállalkozásoknak, de sokkal óvatosabban, körültekintőbben és - a kulcsszó - tudatosabban.

- Körülöttünk a világ társadalmi és gazdasági rendszerei turbulensen változnak, gondoljunk csak az ipar 4.0 eszköztárára (digitalizáció, robotizáció, mesterséges intelligencia). Egy olyan innovatív ökoszisztéma kialakulásának lehetünk 
szemtanúi, amelyek változtatást igényelnek a vállalati szereplốk részéról is. Tudatosan alkalmazni, integrálni szükséges azon innovatív megoldásokat, amelyek jelentôsen javíthatják a hazai vállalatok hatékonyságát és eredményességét. Az innovatív megoldások szintén kimagasló jelentôséggel bírnak.

- A fenti gondolatok is elórevetítik azt, hogy a vállalkozásoknak különösen jelentôs energiát szükséges fordítaniuk az egyik legfontosabb erôforrásra, azaz a humán tốkére. A humántốke-beruházás, a folyamatos képzés, szakmai megújulás szintén védekezố mechanizmusként szolgálhat minden vállalkozás életében. De nem csupán védekezô mechanizmusként, hanem kiemelt fontosságú versenyképességi tényezóként is értelmezhetô mindez. Ma már egyértelmú, hogy amely szervezet növekedni akar, ott a tudás az egyik legfontosabb tényezố.

- Végül pedig érdemes megjegyezni a vállalati kultúra jelentôségét, amelyet a vállalatok saját maguk tudnak kialakítani. Ez az, ami erôsíti a vállalatok alkalmazottainak összetartozás-érzését, ami pedig lehetôséget teremt arra, hogy szoros együttmúködésben legyenek képesek reagálni az esetlegesen bekövetkezô, nem várt eseményekre.

Az elózốekbôl is látható, hogy a pénzügyi kultúra fejlesztése kiemelkedó feladat napjainkban, hiszen a gazdaság szereplôi kizárólag megfelelô minôségú és mennyiségú információk birtokában képesek felelôs döntéseket hozni. Ilyen többek között a vállalkozások tôkeszerkezetére vonatkozó döntés, amely az eredményes, gazdaságos, hatékony múködésen felül a stabilitás, likviditás, jövedelmezôség és a vállalati versenyképesség egyik zálogának tekinthetô. Éppen ezért, valamint egy esetleges recesszió esetén a gyors reagálás és hatékony kilábalás érdekében, formális vagy informális módon, illetve különbözố mélységben, de minden vállalkozásnak elôretekintőnek kell lennie a pénzügyei tekintetében (is), és tudatosan kell tervezni pénzügyeit, azon belül tốkeszerkezetét. E gondolatmenetet támasztja alá Szóka (2008), aki úgy fogalmaz, hogy a pénzügyek hatékony menedzselése ma már minden vállalkozás számára létszükséglet, hiszen a likviditás megfeleló szabályozása, a helyes befektetési és finanszírozási döntések meghozatala révén erôsödhet a vállalkozás vagyoni, jövedelmezôségi és piaci helyzete, biztosítható a vállalkozás eredményes múködése és hosszú távú fennmaradása. A rossz finanszírozási döntések súlyos akár végzetes - következményekkel is járhatnak. Ahhoz viszont, hogy megfelelô pénzügyi, finanszírozási, azon belül tốkeszerkezetre vonatkozó terveket tudjanak készíteni a vállalkozások, magas szintú pénzügyi kultúrával kell rendelkezniük, tekintettel arra, hogy a finanszírozási szerkezet kialakítása, a források arányának meghatározása az egyik legnehezebb szakmai kérdésnek tekinthetô (Gyulai, 2013). Értjük ez alatt azt, hogy a forrásigény meghatározása után számos tényezô (mint például a finanszírozandó projekt/beruházás típusa, hitelkamatok, kockázat, vállalatméret, vállalati életciklus, gazdasági környezet) együttes figyelembevételével kell kiválasztani azt a forrást, illetve meghatározni a forrásoknak azt az arányát, amely a leginkább megfeleló a vállalkozás számára, mindezt összehangolva a vállalat általános stratégiájával, tekintettel arra, hogy az operatív döntések egyúttal a stratégia megvalósítását, szükség szerint továbbfejlesztését, 
módosítását is jelentik (Sinkovics, 2010). További nehezítô tényezô, hogy valamennyi megvalósítandó cél esetében más és más arány tekinthetố optimálisnak, és ez az optimális arány a külsô, gazdasági-jogi környezet változásával is folyamatosan változik. Tehát a pénzügyi tervezés meglehetôsen összetett múvelet, hiszen a tulajdonosoknak valamennyi gazdasági jellegú döntésük hatásait mérlegelni kell azzal a céllal, hogy a források biztosításával és hatékony elosztásával a vállalkozás pénzügyi helyzetét kedvezô irányba befolyásolják (Túróczi, 2014; Katits, 2002). Továbbá a pénzügyi, gazdálkodási döntések megalapozottsága (szakmai formális tudás) növeli az innovativitás esélyét (Győri-Czakó, 2019).

AZ INNOVÁCIÓ MINT A VERSENYKÉPESSÉG ÉS A FENNTARTHATÓ FEJLÓDÉS TÉNYEZŐJE

Magyarország fenntartható fejlôdése szempontjából, a fentieken túl, különösen fontos, hogy a jelenlegi termelésalapú gazdaság fokozatosan tudásra és innovációra épülő gazdasággá váljon. Ezt támasztja alá az Európai Unió újra napirendre tûzött lisszaboni stratégiája, amely az oktatást, a kutatást és az innovációt magában foglaló „tudásháromszöget” az európai versenyképesség egyik alappilléreként határozza meg (Zéman, 2019).

Miért van szükség innovációra? A jelenlegi digitális transzformáció és technológiaváltás jelentette kihívásra az innováció a válasz. A Magyar Nemzeti Bank a versenyképességi programjában külön kiemelte, hogy a kutatás-fejlesztés és innováció erôsítése elősegítheti a mennyiségvezérelt magyar gazdaság átállását a tudás- és technológiaalapú modellre (MNB, 2019). Látható, hogy azok az országok a legversenyképesebbek, amelyek tudással, innovációval, magas hozzáadott értékkel rendelkeznek. A 21. század a gyors változások korának tekinthetô. Ilyen környezetben azok a vállalkozások lehetnek sikeresek, amelyek képesek arra, hogy előre gondolkodjanak, aktív stratégiát alkossanak, rugalmasak, agilisak és nyitottak legyenek. Tehát kiemelt figyelmet kell fordítani az innováció gyorsítására a teljes értéklánc mentén. Ehhez azonban az kell, hogy a hazai vállalkozások minél több helyen legyenek képesek becsatlakozni a globális értékláncokba. Magyarországon folyamatosan erôsödik a külföldi nagyvállalatok kutatás-fejlesztési tevékenysége, amely lehetôséget biztosíthat arra, hogy ezek a nagyvállalatok pozitív hatást gyakoroljanak a hazai kkv-kra.

Mit jelent ez a humán tôke szempontjából? Magasan képzett szakemberekre van szükség, ami együtt jár a magasabb bérekkel. Az innováció magával hozza a tudásfejlesztést és a bérek emelkedését - ezek pedig szükségesek a teljes nemzetgazdaság versenyképességének javulásához. Az innováció tehát együtt mozog a tudásberuházással. Különösen fontos a felnôttképzés és szakképzés erôsítése, hiszen anélkül akármennyit is fordítunk a technológiákra, digitalizációra és robotizációra, innovációkra, a beruházások hatékonysága alacsony szintú marad. De az egyik legfontosabb feladat mégis a tudásalapú gazdaságra való átállás. „A várható radikális technikai, technológiai fordulathoz megalapozott, széles körú, az egész társadalmat átfogó tudásra van szükség. Az okoseszközök és innovatív megoldások csak okos, felkészült társadalmakban múködnek és múködtethetôk. Aki kimarad a felkészülésbôl, az lemarad a fejlődésben. 


\section{Tudományos múhely}

A közeljövố meghatározó feladata lesz a minôségi tudás előállítása és megfelelô menedzselése, melynek színterei nyilvánvalóan csak az egyetemek lehetnek. Ez esetben a konkrét pénzügyi ismeretek bôvítése, az állam vagy a pénzintézetek által támogatott oktatási formák, ismeretterjesztô anyagok lehetséges eszközt jelenthetnek a helyzet javítására" (Zéman, 2019).

De mit kell tenni ehhez? Kiemelten kell támogatni a magyar kisvállalkozások saját fejlesztéseit, törekvéseit, elképzeléseit. A külföldi tulajdonú cégek aránya meglehetôsen magas a hazai gazdasági szerkezetben, ami kiszolgáltatottságot okoz, hiszen ezek üzleti célja a minél nagyobb profit megszerzése, tehát ezek a cégek nem fejlesztési céllal települnek hozzánk. Ezért leginkább a hazai kkv-szektorból lenne várható az innováció. Milyen támogató környezet szükséges ehhez? Válaszként azt mondhatjuk, hogy a nyitott innováció, aminek lényege, hogy az egyes intézmények, szervezetek nem önállóan, saját erôforrásaikra támaszkodva végzik innovációs tevékenységüket, hanem a pénzügyi és humán erôforrások lehetô leghatékonyabb hasznosítása érdekében együttmúködnek egymással. Ehhez pedig az szükséges, hogy az üzleti szféra és az egyetem között hatékony együttmúködés alakuljon ki.

Magyarország GDP-termelô képessége szempontjából érdemes megvizsgálni a kkv-szektor hozzáadottérték-termeló képességét, amely viszonylag gyengének mondható. Ez az érték 50-55\% körül mozog, miközben Ausztriában 60 százalék felett van. Amennyiben megerôsítjük a kkv-szektort pl. innováció révén, azzal fokozható a GDP-termelố képességük is. Az innováció pedig hozzájárul a ter- melékenység, hatékonyság és versenyképesség javításához is. Az innovációs teljesítmény gyengesége hatással van a versenyképességre is. De milyen innovációra van szükség? Hangsúlyozni szükséges, hogy nemcsak termék- és technológiai, hanem szervezési, marketing- és vezetési innováció is szükséges, tekintve, hogy folyamatosan jelennek meg az új üzleti modellek.

A nagy versenyképességi kutatások részletesen és folyamatosan elemzik ezeket a területeket, a Világgazdasági Fórum (World Economic Forum, WEF) 2019. október elején tette közzé legfrissebb elemzését. Az elemzésbốl kiderül, hogy hazánk egy helyet javított, és így a 28 tagú Európai Unióból a 24. helyen áll, a globális listán pedig a 47. lett. A hazai adatokat tekintve megállapítható, hogy a makrogazdaság kitúnóen teljesít, így az infláció, az államadósság mértéke és a munkaerố-kihasználtság is kitûnônek tekinthetố (Schwab, 2019).

Természetesen vannak gyenge pontok is, amelyek fejlesztésre szorulnak a jövôben. Ezek közül az egyik terület pontosan a kutatás-fejlesztési mutatók, amelyek tekintetében problémaként értelmezhetô, hogy a hazai $\mathrm{K}+\mathrm{F}+\mathrm{I}-$-eredményeket nem sikerült átültetni a gyakorlatba. Megjegyezzük továbbá az oktatás jelentôségét, amely szorosan összefügg a versenyképességi helyzetünk javításával: a magas színvonalú, topmodern technológiák tömeges meghonosításához versenyképes vállalkozásokra és magas tudásszintre van szükség.

Meggyôzôdésünk, hogy a vállalatok versenyképességi helyzetének drasztikus javításával Magyarország folytathatja azon növekedési és stabilizációs trendjét, amely már évek óta jellemzi hazánkat. 


\section{Tudományos múhely}

\section{JEGYZETEK}

1 Dr. Findrik Mária egyetemi magántanár véleménye alapján, kiegészítve.

2 www.mfb.hu/vallalkozasok/mukodo/tokebefektetesek/mfb-generaciovaltasi-tokeprogram-t121-p121.

\section{FelHaSZnÁlt IRODALOM}

Bod Péter Ákos (2018): Magyar gazdaságpolitika túzközelbôl. Akadémiai Kiadó, Budapest.

Gorton, Gary B. (2012): Misunderstanding Financial Crises. Why We Don't See Them Coming. Oxford University Press, New York.

Gyốri Ágnes - Czakó Ágnes (2019): Innováció és pénzügyi-gazdálkodói kultúra: Az innovációs aktivitás egyes magyarázó tényezôi a kkv-szektorban. Szociológiai Szemle, 29. évf., 1. sz., 85116.

Gyulai László (2013): Kis- és középvállalkozások üzletflnanszírozása. Saldo Kiadó, Budapest.

Heidrich Balázs (2018): Generációváltás - Nem csak papíron kell lejátszani. Világgazdaság, www.vg.hu/velemeny/elemzes/generaciovaltas-nem-csak-papiron-kell-lejatszani-2-1226494/.

Katits Etelka (2002): Pénzügyi döntések a vállalat életciklusaiban. KJK-Kerszöv Jogi és Üzleti Kiadó, Budapest.

Konczosné Szombathelyi Márta - Kézai Petra (2018): Családi vállalkozások - generációk és dilemmák. Prosperitas, 5. évf., 3. sz., 48-76, http:// dx.doi.org/10.31570/Prosp_2018_03_3.

Kovács Levente (2015): A pénzügyi kultúra kutatása és aktuális feladataink. Bankszövetség, www.bankszovetseg.hu/Public/gep/2015/Kovacs-Levente-79-88.pdf.

Lentner Csaba (2019): A magyar állampénzügyek fejlódéstörténete a dualizmus korától napjainkig. L'Harmattan, Budapest.

Magyar Kereskedelmi és Iparkamara, Közgazdasági Igazgatóság belsố tanulmányai.
MKIK (2019): Gazdasági tájékoztató harmadik negyedév. Magyar Kereskedelmi Kamara, szeptember 25.

MNB (2019): Versenyképességi program 330 pontban. Magyar Nemzeti Bank, Budapest, www.mnb. hu/letoltes/versenykepessegi-program.pdf.

Pula Gábor (2005): Az euró bevezetésével járó strukturális politikai kihívások: munkapiac. MNB-tanulmányok, 41., Budapest.

Schwab, Klaus (ed.) (2019): The Global Competitiveness Report 2019. World Economic Forum, http:// www3.weforum.org/docs/WEF_TheGlobal CompetitivenessReport2019.pdf.

Sinkáné Csendes Ágnes (2018): Hogyan javítsunk az adómorálon? SZAKma, 60. évf., 3. sz., 14-15.

Sinkovics Alfréd (2010): Vállalati pénzügyi tervezés. CompLex Kiadó, Budapest.

Szóka Károly (2008): Kis- és középvállalkozások elôremutató pénzügyi tervezési lehetôségei. In: III. Kheops Tudományos Konferencia tanulmánykötet, http://spek.hu/anyagok/Dr_Szoka_Karoly_Kheops_cikk.pdf.

Tebeli Izabella (2018): A pénzügyi tudatosság fejlesztését célzó stratégia. SZAKma, 60. évf., 3. sz., 6-8.

Tóth Róbert - Túróczi Imre - Gyurcsik Petronella (2018): A pénzügyi kultúra értelmezése a hazai mezôgazdasági vállalkozások vonatkozásában I. A Falu, 33. évf., 1. sz., 77-85.

Túróczi Imre (2014): A pénzügyi és vezetôi számviteli módszerek alkalmazhatósága a vállalatértékelés gyakorlatában. Economica, 7. évf., 1. sz., 134-139.

Vakhal Péter - Palócz Éva (2018): Fél pohár víz, avagy hogyan értelmezhetô a magyar versenyképesség az objektív és szubjektív mutatók szerint. In: Kolosi Tamás - Tóth István György (szerk.): Társadalmi Riport 2018. Tárki Zrt., 217-232.

Zéman Zoltán (2019): A gazdaságtudomány magyarországi helyzete és kapcsolódási pontjai a gazdasági fejlesztésekkel. Polgári Szemle, 15. évf., 1-3. sz., 298-305, https://doi. org/10.24307/psz.2019.0919. 